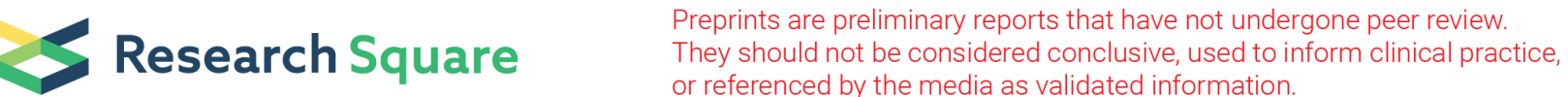

\section{Simultaneous High-Efficiency Removal of Sulfamethoxazole and zinc (II) From Livestock and Poultry Breeding Wastewater by a Novel Dual- Functional Bacterium, Bacillus sp. SDB4}

\section{Xi Chen}

University of Science and Technology Beijing

Hai Lin ( $\sim$ linhai@ces.ustb.edu.cn )

University of Science and Technology Beijing

Yingbo Dong

University of Science and Technology Beijing

Bing Li

University of Science and Technology Beijing

Tingting Yin

University of Science and Technology Beijing

Chenjing Liu

University of Science and Technology Beijing

\section{Research Article}

Keywords: Combined contaminants, Antibiotic, Heavy metal, Bacillus paramycoides bacteria,

Bioremediation, Simultaneous removal.

Posted Date: May 11th, 2021

DOI: https://doi.org/10.21203/rs.3.rs-446677/v1

License: (9) This work is licensed under a Creative Commons Attribution 4.0 International License.

Read Full License

Version of Record: A version of this preprint was published at Environmental Science and Pollution Research on August 27th, 2021. See the published version at https://doi.org/10.1007/s11356-021-158043. 


\section{Abstract}

The complex mixtures of antibiotics and heavy metals are commonly existed in livestock and poultry breeding wastewater. Effective and simultaneous removal of these toxic compounds by microorganisms, especially single strains remains a considerable challenge. In this study, a novel functional strain SDB4, isolated from duck manure and identified as Bacillus sp., has been shown to possess high removal abilities for both sulfamethoxazole (SMX) and $\mathrm{Zn}^{2+}$. The maximum removal efficiency achieved $73.97 \%$ for SMX and $84.06 \%$ for $\mathrm{Zn}^{2+}$ within $48 \mathrm{~h}$ in sole system. It has great potential for eliminating SMX along with $\mathrm{Zn}^{2+}, 78.45 \%$ of SMX and $52.91 \%$ of $\mathrm{Zn}^{2+}$ were removed in the $20 \mathrm{mg} \cdot \mathrm{L}^{-1} \mathrm{SMX}$ and $100 \mathrm{mg} \cdot \mathrm{L}^{-1} \mathrm{Zn}^{2+}$ binary system. Furthermore, the SMX-biotransformation ability of SDB4 was enhanced at low concentrations of $\mathrm{Zn}^{2+}$ (below $100 \mathrm{mg} \cdot \mathrm{L}^{-1}$ ). $\mathrm{N}^{4}$-acetyl-SMX was identified as the main stable transformation product during SMX bioremoval. FTIR analyses revealed that $\mathrm{OH}, \mathrm{NH}_{2}, \mathrm{C}=\mathrm{O}, \mathrm{C}-\mathrm{N} / \mathrm{N}-\mathrm{H}$ and $\mathrm{C}-0-\mathrm{C}$ played major roles in the biosorption of $\mathrm{Zn}^{2+}$. Our study of the dually functioning strain SDB4 provides a potential application for the simultaneous biological removal of antibiotics and heavy metals.

\section{Introduction}

With the dietary evolution of humans, the actual scale of global animal rearing and meat production has increased, resulting in intensification of livestock farming (Tullo et al. 2019). In contrast with traditional feeding methods, livestock diseases are increasingly complex in the intensive and large-scale feeding industry. These diseases spread rapidly and cause huge economic losses once outbreak becomes endemic. Consequently, antibiotics such as sulfonamides and tetracyclines, have been widely used to prevent livestock diseases (Shao et al. 2020). At the same time, heavy metals including zinc and copper have also been extensively used as feeding additives to increase production (Li et al. 2019). However, only partial antibiotics/heavy metals can be metabolized/absorbed by livestock, causing a large number of residues in the excreta (Liu et al. 2016; Xu et al. 2016). These elements are readily accessible to the land and easily entered the water through leaching and direct runoff, thereby spreading drug and heavy metal contamination (Lillenberg et al. 2010; Pan et al. 2018; Trenouth and Gharabaghi 2015). The commonly coexistence of antibiotics and heavy metals in high concentrations in livestock farming wastewater generate combined contamination (Riaz et al. 2020). Over time, high levels of complex contaminants also contribute to the accumulation of antibiotic resistance bacteria (ARB) and antibiotic resistance genes (ARGs) (Chen et al. 2018; Christou et al. 2017). The compound pollution of antibiotics and heavy metals in aquatic environments has become an international problem, causing harm to human life and ecological health (He et al. 2017; Hou et al. 2019; Xing and Jin 2018). Therefore, it is urgently needed to remove the combined contaminants from aquaculture wastewater.

The removal of antibiotics and heavy metals from wastewater is a challenging issue, since the complicated characteristics of combined contamination. Different sorts of composite pollutants have complicated properties (hydrophobic/hydrophilic, negative/positive surface charge characteristics, etc.), which makes the treatment of wastewater even more difficult (Ma et al. 2014). Several physical-chemical 
methods have been adopted to simultaneously remove antibiotics and heavy metals. Some studies of flocculants were investigated for their synergistic removal potential of antibiotics and heavy metals, and flocculation mechanisms of combined pollutants were proposed (Hou et al. 2019; Zhang et al. 2014). Antibiotics and heavy metals could be absorbed by some special materials. The capability of hybrid silicate-hydrochar composite to remove tetracycline, $\mathrm{Cu}^{2+}$ and $\mathrm{Zn}^{2+}$ was investigated (Deng et al. 2020). Shao et al. explored the synthesis and application of nanoscale zero-valen iron in simultaneous chlortetracycline and $\mathrm{Cu}^{2+}$ removal, the removal mechanisms of combined pollutants were also studied (Shao et al. 2020). Ma et al. indicated that ciprofloxacin and $\mathrm{Cu}^{2+}$ can be removed simultaneously by coadsorption using graphene hydrogels (Ma et al. 2020). However,traditional physical and chemical methods require high cost, spend a lot of material resources, and even introduce new pollutants, limiting the application. Microbial remediation, a competitor in environmental engineering due to its costeffectiveness and environmental friendliness for simultaneous treatment of various chemical pollutants, could be an alternative to traditional chemical and physical technologies (Shah and Shah 2020; Verma and Kuila 2019). The bioremoval of antibiotics or heavy metals has been extensively studied in the literature (Chen and Xie 2018; Qin et al. 2020). Nevertheless, only a few articles have reported simultaneous bioremoval of antibiotics and heavy metals by microbial consortia in long time ( 12 days) (Al-Gheethi et al. 2015). Limited information was available about the removal performance of microorganisms, especially single strains in shorter time. Meanwhile, the differences of bioremoving mechanisms between antibiotics/heavy metals single and antibiotics-heavy metals binary systems are still unclear. Hence, it is essential to isolate pure bacterium with antibiotics and heavy metals simultaneous removal ability and study its further use in aquaculture wastewater microbial remediation.

In this study, SMX and $\mathrm{Zn}^{2+}$ were selected as models due to the intensive use in poultry feeding industry (Li et al. 2019; Shao et al. 2020). A novel aerobic strain SDB4, isolated from duck manure and identified as Bacillus sp. based on its physiological characteristics and 16S rRNA sequence, was applied for simultaneous removal of SMX and $\mathrm{Zn}^{2+}$. The purposes of this study were to (1) isolate and identify a dual-functional strain from duck manure, (2) access the bioremoval characteristics of SMX or/and $\mathrm{Zn}^{2+}$ by strain SDB4 under single and binary systems, and (3) examine the bioremoval mechanisms of SMX and $\mathrm{Zn}^{2+}$ by strain SDB4. This study will provide theoretical basis for strain SDB4 in treating actual aquaculture wastewater.

\section{Materials And Methods}

\subsection{Medium and chemicals}

Luria-Bertani (LB) medium was prepared by mixing $10 \mathrm{~g} \cdot \mathrm{L}^{-1}$ tryptone, $5 \mathrm{~g} \cdot \mathrm{L}^{-1}$ yeast extract and $10 \mathrm{~g} \cdot \mathrm{L}^{-1}$ $\mathrm{NaCl}$ in $1000 \mathrm{~mL}$ deionized water, adjusted to $7.0 \mathrm{pH}$ using $\mathrm{NaOH}$. In total, the solid medium was prepared by adding $1.5-2.0 \%(\mathrm{w} / \mathrm{v})$ agar. All media were autoclaved for $30 \mathrm{~min}$ at $121^{\circ} \mathrm{C}$ before use. 
SMX was purchased from Aladdin Company with purity above 98\% (China). Zinc sulfate heptahydrate and other reagents were all analytical grade purchased from Tianjin Damao Chemical Reagent Factory, China.

\subsection{Screening $S M X-Z \mathrm{n}^{2+}$ resistant and bioremoving bacteria}

In order to enrich SMX and $\mathrm{Zn}^{2+}$ resistant strain, which was isolated from the duck manure collected from a farm in Shandong, China, an aliquot of $10 \mathrm{~g}$ duck droppings was added to $100 \mathrm{~mL}$ of sterile growth LB medium containing $5 \mathrm{mg} \cdot \mathrm{L}^{-1} \mathrm{SMX}$ and $5 \mathrm{mg} \cdot \mathrm{L}^{-1} \mathrm{Zn}^{2+}$ in a $250 \mathrm{~mL}$ conical flask. After 5 days of incubation at $30^{\circ} \mathrm{C}$ and $150 \mathrm{rpm}$ in the dark, $10 \mathrm{~mL}$ enrichment suspensions were transfer to $100 \mathrm{~mL}$ fresh LB containing $10 \mathrm{mg} \cdot \mathrm{L}^{-1} \mathrm{SMX}$ and $10 \mathrm{mg} \cdot \mathrm{L}^{-1} \mathrm{Zn}^{2+}$. The enrichment process was continued 9 times using the same methods, with both $\mathrm{SMX}$ and $\mathrm{Zn}^{2+}$ concentrations increased by $5 \mathrm{mg} \cdot \mathrm{L}^{-1}$ during each inoculation period until the concentrations both reached $50 \mathrm{mg} \cdot \mathrm{L}^{-1}$ in LB. After 45 days, the concentrated suspensions were coated on LB agar plates and grown at $30^{\circ} \mathrm{C}$ in constant temperature and dark environment. Ten isolated colonies were extracted and purified by repeated streaking on the fresh LB agar plates. The purified strains with SMX and $\mathrm{Zn}^{2+}$ resistance were cultivated in fresh $\mathrm{LB}$ to test the removal efficiency of SMX/Zn. Finally, SDB4 showed the best SMX bioremoval ability.

\subsection{Identification of dual-functional strain}

According to the manufacturer's instructions, genomic DNA was extracted with the Bacterial Genome DNA Extraction Kit (Tiangen Biotech Co., Ltd.). The following primers were used to amplify the PCR of the gene encoding $16 \mathrm{~S}$ rRNA: $27 \mathrm{f}$ and 1492 $\mathrm{r}$ was the forward and reverse primer, respectively (Pan et al. 2018). The PCR products were sequenced in MajorBio (Shanghai, China).

The IDENTIFY tool was used for comparing the sequence with the available DNA sequences in EzTaxon (http://www.ezbiocloud.net/eztaxon). MEGA version 7.0 software was used to analyze the phylogenesis, and the phylogenetic tree was constructed with the neighbor-joining method.

\subsection{Experiments design}

In the single pollution system, to determine SMX/Zn ${ }^{2+}$ bioremoval capability, firstly, SDB4 was firstly grew in LB medium at $30^{\circ} \mathrm{C}$ and shaked with a speed of $150 \mathrm{rpm}$. The cells were harvested 24 hours later and centrifuged at $8000 \mathrm{rpm}$ for $15 \mathrm{~min}$ at $4^{\circ} \mathrm{C}$. After centrifugation, the SDB4 cells were then washed three times with $0.9 \%$ sterilized sodium chloride solution. The suspensions of SDB4 cell were finally transferred to sterilized LB liquid medium containing SMX/Zn ${ }^{2+}$ for the bioremoval of SMX/Zn ${ }^{2+}$. The bioremoval experiments were performed in a batch of $250 \mathrm{~mL}$ flasks. The samples were collected periodically for determining $\mathrm{SMX} / \mathrm{Zn}^{2+}$ concentrations.

Harmful effects were caused by the accumulation and persistence of antibiotics in various environmental conditions, meanwhile heavy metals are commonly occur together with antibiotics in livestock and poultry wastewater (Shao et al. 2020; Zhang et al. 2017). So a wide range of environmental factor and 
the effect of heavy metals on SMX bioremoval have been explored during the study. Based on the previous preliminary experiments of SMX bioremoval, four groups of experiments were designed. Various SMX concentrations $\left(20-800 \mathrm{mg} \cdot \mathrm{L}^{-1}\right), \mathrm{pH}(4.0-10.0)$, temperature $\left(15-40^{\circ} \mathrm{C}\right)$ and $\mathrm{Zn}^{2+}$ concentrations $\left(20-250 \mathrm{mg} \cdot \mathrm{L}^{-1}\right)$.

The above four groups of experiments were all carried out under sterile conditions; the initial concentration of SMX was all $20 \mathrm{mg} \cdot \mathrm{L}^{-1}$ except the SMX concentration influence test; and all flasks were wrapped in aluminum foil to prevent SMX photodegradation.

$\mathrm{Zn}^{2+}$ bioremoval experiments were performed in flasks containing $100 \mathrm{~mL}$ LB liquid medium supplemented with single metal $\left(20-250 \mathrm{mg} \cdot \mathrm{L}^{-1}\right)$.

In the binary pollution system, in order to investigate the removal efficiencies of complex pollutants by SDB4, the SMX-Zn ${ }^{2+}$ binary system in LB liquid medium consists of $20 \mathrm{mg} \cdot \mathrm{L}^{-1} \mathrm{SMX}$ and $100 \mathrm{mg} \cdot \mathrm{L}^{-1}$ $\mathrm{Zn}^{2+}$.

\subsection{Analytical methods}

The changes of bacterial concentration were monitored by a UV-1100 ultraviolet spectrophotometer (Mapada in China) at $600 \mathrm{~nm}$ and expressed as OD value.

Briefly, $2 \mathrm{ml}$ samples were extracted from each flask, and filtered through a $0.45 \mathrm{~m}$ filter membrane to remove impurities and biomass, then stored at $4^{\circ} \mathrm{C}$ for further measurement. SMX was tested by highperformance liquid chromatography (HPLC) (Agilent 1200 Series). The determination conditions and the mobile phase composition were set as reported previously (Wang and Wang 2018).

The biotransformation metabolites of SMX were analyzed by Ultra-high-pressure liquid chromatography tandem mass spectrometry (UHPLC-MS-MS, Ultimate 3000/Q-Exactive, USA). Acquity ${ }^{\circledR}$ UPLC $\circledast$ BEH C18, $1.7 \mu \mathrm{m}, 50 \times 2.1 \mathrm{~mm}$ column (Waters Corporation) was used. The flow rate was $600 \mathrm{uL} \cdot \mathrm{min}^{-1}$ and the volume of injection was $5 \mathrm{uL}$. The mobile phases were (A) water-methanol $(95: 5 \%, \mathrm{v} / \mathrm{v})$ containing $0.1 \%$ acetic acid and (B) acetonitrile-methanol (50:50\%, v/v) containing $0.1 \%$ acetic acid. The chromatographic analysis was performed in gradient mode, starting at $90 \% \mathrm{~A}$, holding for $1 \mathrm{~min}$, and then rising to $90 \% \mathrm{~B}$ within $6 \mathrm{~min}$. The electrospray interface (ESI) was provided on the mass spectrometer, and the ESI source was operated in positive ionization mode with the ionspray voltage set for $4.0 \mathrm{kV}$ at $300 \circ \mathrm{C}$. Full scans were obtained from m/z 50-600 to identify the metabolites. Metabolites in single SMX system and SMX$\mathrm{Zn}^{2+}$ binary system were identified by comparing with standard compounds.

The residual $\mathrm{Zn}^{2+}$ concentration in the solution was determined using the inductively coupled plasma optical emission spectrometry (ICP-OES) method.

Fourier transform infrared spectroscopy (FTIR) was used to analyze the changes of functional groups in control sample (without adding pollutants), $100 \mathrm{mg} \cdot \mathrm{L}^{-1} \mathrm{Zn}^{2+}$ contaminated samples, $20 \mathrm{mg} \cdot \mathrm{L}^{-1} \mathrm{SMX}$ 
and $100 \mathrm{mg} \cdot \mathrm{L}^{-1} \mathrm{Zn}^{2+}$ co-contaminated samples. The scanning range was $500-4000 \mathrm{~cm}^{-1}$, resolution of $4 \mathrm{~cm}^{-1}$, and scanning frequency of 32 .

\subsection{Statistical analysis}

All the experiments were repeated three times and the results were averaged. The bioremoval efficiency

(\%) was calculated by the following equations:

Bioremoval efficiency $(\%)=\frac{\left(C_{0}-C_{\mathrm{t}}\right) * 100}{C_{0}}$

where $\mathrm{C}_{0}\left(\mathrm{mg} \cdot \mathrm{L}^{-1}\right)$ and $\mathrm{C}_{\mathrm{t}}\left(\mathrm{mg} \cdot \mathrm{L}^{-1}\right)$ are $\mathrm{SMX}$ or $\mathrm{Zn}^{2+}$ concentration in solution at initial and time $\mathrm{t}$, respectively.

\section{Results And Discussion}

\subsection{Isolation and identification of the dual-functional strain}

The dual-functional strain SDB4, isolated from the duck manure, could grow on solid LB medium with both SMX and $\mathrm{Zn}^{2+}$. Strain SDB4 is an aerobic gram-negative strain, and waxy, circular, non-translucent colonies were formed on LB solid plate. The partial 16S rRNA gene sequence analysis of strain SDB4 (1426 bp, GenBank accession number: MT647568) showed a close relationship to the genus Bacillus and the similarity to Bacillus paramycoides (GenBank accession number MA0101000012, Bacteria; Firmicutes; Bacilli; Bacillales; Bacillaceae; Bacillus) was 98.59\%.

Based on the morphological characteristics and phylogenetic analysis, SDB4 was identified as Bacillus paramycoides. According to the 16S rRNA gene sequences and other close phylogenetically relatives, the phylogenetic tree was constructed (Fig. 1). Bacillus paramycoides is a novel specie of the Bacillus cereus group, originally isolated from a diverse marine environment (Liu et al. 2017). There are few studies on its resistance to antibiotics/heavy metals. It is the first manuscript of a strain belonged to Bacillus sp., which could simultaneously bioremove SMX and $\mathrm{Zn}^{2+}$.

\subsection{Bioremoval performance of SMX by strain SDB4 3.2.1. Effect of initial concentration on SMX bioremoval}

Six initial SMX concentrations $\left(20,50,100,200,400\right.$ and $\left.800 \mathrm{mg} \cdot \mathrm{L}^{-1}\right)$ were adopted to investigate the effect of SMX concentration on SMX bioremoval efficiency by strain SDB4. The inoculation dose was $10 \%(\mathrm{v} / \mathrm{v})$, the initial $\mathrm{pH}$ was set as 7 and the temperature was adjusted to $30^{\circ} \mathrm{C}$. When SDB4 was added to $L B$, the bacteria growth and SMX removal efficiency gradually decreased with the increase of SMX concentration. Figure 2a, b show the remained concentration ranged from 6 to $310 \mathrm{mg} \cdot \mathrm{L}^{-1}$ when the average initial concentration of SMX changed from 20 to $800 \mathrm{mg} \cdot \mathrm{L}^{-1}$, of which the SMX removal 
efficiency within 48 hours was $72.96,70.14,68.38,66.93,64.85$, and $61.62 \%$, respectively. With an initial concentration of SMX is $20 \mathrm{mg} \cdot \mathrm{L}^{-1}$, the SMX removal efficiency reached a maximum of $72.96 \%$.

With the increasement of SMX initial concentration, the removal rate of SDB4 was enhance. Assessing the initial SMX concentration from 20 to $800 \mathrm{mg}^{\cdot \mathrm{L}^{-1}}$, the bioremoval rate of SDB4 in 48 hours was 0.31 , $0.78,1.55,2.93,5.48$, and $10.38 \mathrm{mg} \cdot \mathrm{L}^{-1} \cdot \mathrm{h}^{-1}$, respectively. Previous study indicated that some bacterium occurred very fast SMX bioremoval rate of $5.0 \mathrm{mg} \cdot \mathrm{L}^{-1} \cdot \mathrm{h}^{-1}$ (Wang and Wang 2018). Results in this study showed higher SMX bioremoval capacity compared with previous studies. SDB4 is capable of utilizing SMX as a co-metabolic carbon source, exhibit an excellent bioremoval ability in a wide range of initial SMX concentration and can withstand the selection pressure of $800 \mathrm{mg} \cdot \mathrm{L}^{-1} \mathrm{SMX}$.

\subsubsection{Effect of pH on SMX bioremoval}

$\mathrm{pH}$ is an important factor affecting microbial physiology, the solubility and ionic state of organic pollutants, thereby affecting the ability of microorganisms to degrade organic pollutants (Wang and Wang 2018; Zhang et al. 2017). Figure 2c,d depict the effect of different initial pH on the bioremoval of SMX by strain SDB4. The effects of $\mathrm{pH}$ value on SMX removal and bacterial growth were investigated under the conditions of $\mathrm{pH} 4.0-10.0$. When the $\mathrm{pH}$ was maintained at $4,5,6,7,8,9$ and 10 , the removal efficiency obtained was $45.25,47.88,63.42,73.97,67.58,65.02$ and $51.60 \%$, respectively, within 48 hours under conditions of $20 \mathrm{mg} \cdot \mathrm{L}^{-1}$ initial concentration and $30^{\circ} \mathrm{C}$ temperature. The highest SMX removal efficiency for strain SDB4 was observed to be $73.97 \%$ at pH 7. Similar results have also been reported in other biodegradants such as Achromobacter sp. S-3 and Acinetobacter sp. W1 (Huang et al. 2012; Wang and Wang 2018). This behavior caused by $\mathrm{pH}$ might be due to the negative effects of certain extreme $\mathrm{pH}$ values on functional enzyme (Lin et al. 2014).

Compared with acidic environment $(\mathrm{pH} 4-6)$, neutral and alkaline environment $(\mathrm{pH} 7-10)$ were more conducive to the bioremoval of SMX. There are two pKa values for SMX. It is present in the form of cation when the $\mathrm{pH}$ is below 1.6; It exists as the form of anion at a pH higher than 5.7; and when the $\mathrm{pH}$ value is between 1.6 and 5.7, it is in the form of neutral. The anion form is more easily degraded than other two forms in the process of AOPs (Qi et al. 2014). Similar information is available for biodegradation of SMX. Wang's research showed that Acinetobacter sp. was able to degrade SMX better in neutral and alkaline environment than acidic environment (Wang and Wang 2018). Thus, these results indicate that SDB4 can remove SMX effectively in mildly alkaline $(\mathrm{pH} 7-10)$ media. Based on the results above, SMX was bioremoved by SDB4 and occurred at a wide $\mathrm{pH}$ range, indicating that this strain might have a good application prospect.

\subsubsection{Effect of temperature on SMX bioremoval}

The temperature also significantly affects the biological removal of harmful substances by organisms (Zhang et al. 2017). Temperature is capable to change the activity of microorganism and solubility of SMX greatly (Wang and Wang 2018). In general, the solubility of SMX increased with temperature. However, there is an optimum temperature for the microbial activity of certain microorganism. In this 
study, SMX bioremoval efficiency by SDB4 were studied at different temperatures from 15 to $40^{\circ} \mathrm{C}$. Figure $2 e$ shows the decrease in SMX concentration over time at all test temperatures. As shown in Fig. $2 f$, the removal efficiency of $S M X$ at $15,20,25,30,35$ and $40^{\circ} \mathrm{C}$ was $26.37,40.30,47.43,73.96,66.74$ and $41.47 \%$, respectively. Lowest or highest temperature will inhibit the growth of bacteria, resulting in a decrease in removal efficiency. In addition, the bioremoval rate of SMX reached to higher values of 0.318 and $0.280 \mathrm{mg} \cdot \mathrm{L}^{-1} \cdot \mathrm{h}^{-1}$ at 30 and $35^{\circ} \mathrm{C}$, respectively. Therefore, SDB4 is an effective SMX bioremoval bacterium, with optimal temperature between 30 and $35^{\circ} \mathrm{C}$.

In the actual environment, the dependence of the strain on the ambient temperature will affect the bioremoval ability of SMX, which may cause the bioremediation effect be lower than expected (Deng et al. 2014). Fortunately, the strain SDB4 was able to grow and remove SMX at all test temperatures, though the bioremoval efficiency was reduced at low or high temperature.

\subsubsection{Effect of $\mathrm{Zn}^{2+}$ on SMX bioremoval}

To investigate the effect of the coexistence of $\mathrm{Zn}^{2+}$ on SMX bioremoval, 20-200 $\mathrm{mg} \cdot \mathrm{L}^{-1} \mathrm{Zn}^{2+}$ were added to the SMX solution with initial concentration of $20 \mathrm{mg} \cdot \mathrm{L}^{-1}$. The effects of initial $\mathrm{Zn}^{2+}$ concentrations on SMX removal were estimated by the SMX bioremoval efficiencies as shown in Fig. $2 \mathrm{~g}$. It was obvious to notice that SMX removal efficiency varied with $\mathrm{Zn}^{2+}$ concentration. The presence of $\mathrm{Zn}^{2+}$ (under 100 $\mathrm{mg} \cdot \mathrm{L}^{-1}$ ) provided a slight stimulating effect on SMX removal. Compared to single SMX pollution system, SDB4 showed a more outstanding SMX removal ability in SMX-Zn ${ }^{2+}$ combined pollution system, whereas a higher concentration (100-200 $\mathrm{mg} \cdot \mathrm{L}^{-1}$ ) exerted inhibition influence. Meanwhile, the concentration of bacteria decreased with the increase of $\mathrm{Zn}^{2+}$ addition (Fig. $2 \mathrm{~h}$ ).

As the $\mathrm{Zn}^{2+}$ concentration increased from 20 to $100 \mathrm{mg} \cdot \mathrm{L}^{-1}$, the removal efficiency of SMX in the medium increased from $74.09-78.06 \%$, which was higher compared to that without $\mathrm{Zn}^{2+}$ in $48 \mathrm{~h}$ reaction time. At low concentrations of $\mathrm{Zn}^{2+}$ coexistence, SMX removal efficiency could be enhanced by accelerating the transportation of SMX from extracellular solution to inside cells and the formation of enzyme-metalsubstrate complexes. $\mathrm{Zn}^{2+}$ accelerated SMX removal through uptaking more pollutants inside cells, meanwhile it might work as a cofactor for protein binding and be required for protein biological activity (Tang et al. 2016). The SMX removal efficiency decreased to 51.14 and $41.74 \%$ at 150 and $200 \mathrm{mg} \cdot \mathrm{L}^{-1}$ of $\mathrm{Zn}^{2+}$ concentration addition, it might be attributed to the inhibiting effect of $\mathrm{Zn}^{2+}$ over strian SDB4 resulting in lower removal effeciencies of SMX, $\mathrm{Zn}^{2+}$ may inhibit the activity of enzymes by combining with the sulfhydryl groups of the proteins. Additionally, superabundant $\mathrm{Zn}^{2+}$ competes with macronutrients $\left(\mathrm{Mg}^{2+}, \mathrm{Ca}^{2+}\right.$ etc.), which are commonly used as cofactors for the formation of enzymemetal-substrate complexes (Sherameti and Varma 2010).

\subsection{Bioremoval performance of $\mathrm{Zn}^{2+}$ by strain SDB4}

The effect of initial concentration on $\mathrm{Zn}^{2+}$ bioremoval by SDB4 was investigated under the temperature of $30^{\circ} \mathrm{C}$ and $\mathrm{pH}$ of 7 . Figure $3 \mathrm{a}$, b shows the $\mathrm{Zn}^{2+}$ bioremoval efficiency decreased with the increase of 
initial $\mathrm{Zn}^{2+}$ concentration. As the initial concentration of $\mathrm{Zn}^{2+}$ was $20 \mathrm{mg} \cdot \mathrm{L}^{-1}$, the $\mathrm{Zn}^{2+}$ removal efficiency and strain biomass reached the maximum, which were $84.06 \%$ and 16.51 , respectively. The removal efficiencies were all above $70 \%$ with the initial $\mathrm{Zn}^{2+}$ concentration increased from $20 \mathrm{mg} \cdot \mathrm{L}^{-1}$ to 150 $\mathrm{mg} \cdot \mathrm{L}^{-1}$, while the bacterial growth were decreased. However, the $\mathrm{Zn}^{2+}$ removal efficiencies decreased sharply to $67.40 \%$ and $55.36 \%$ when the initial $\mathrm{Zn}^{2+}$ concentration increased to $200 \mathrm{mg} \cdot \mathrm{L}^{-1}$ and 250 $\mathrm{mg} \cdot \mathrm{L}^{-1}$, respectively. The strain biomass slowly grow of $\mathrm{OD}_{600} 10.03$ and 7.98 . This result may be due to high initial metal ion concentration leading to heavy metal toxicity that inhibits bacterial growth. The rapid decline in removal efficiency may be due to the lack of sufficient free radicals for metal microbial adsorption. It is possible that all metal ions can have good interaction with the binding sites at lower concentrations, resulting in higher removal efficiencies of $\mathrm{Zn}^{2+}$. Similar conclusions have been summarized by other researchers (Jin et al. 2013; Xu et al. 2019). Therefore, the removal efficiency of SDB4 as adsorbent treating low concentration zinc pollution is relatively better, and we can adjust the injection amount of SDB4 based on the concentration of pollutants in the actual wastewater.

\subsection{Simultaneous bioremoval SMX and $\mathrm{Zn}^{2+}$ by strain SDB4}

In order to explore the interaction between SMX and $\mathrm{Zn}^{2+}$ bioremoval, the simultaneous removal by SDB4 were conducted in a binary system under the conditions of initial SMX concentration $20 \mathrm{mg} \cdot \mathrm{L}^{-1}$ with adding $100 \mathrm{mg} \cdot \mathrm{L}^{-1}$ of $\mathrm{Zn}^{2+}$. The results are shown in Fig. $4(\mathrm{a}, \mathrm{b}, \mathrm{c})$. Within $0-6 \mathrm{~h}, \mathrm{SDB} 4$ started to fit the medium environment. With $\mathrm{OD}_{600}$ increasing from 1.95 to 6.86 during $6-18 \mathrm{~h}$, organism biomass displayed an exponential phase. However, the cell started to grow slowly in the stationary period (18-48 h), and the reduction of carbon substrate may be the reason for this phenomenon.

In the process of simultaneous removal of SMX and $\mathrm{Zn}^{2+}$ by SDB4, the concentration of SMX and $\mathrm{Zn}^{2+}$ both decreased while the $\mathrm{OD}_{600}$ increased. As the organic carbon sources coexisted with $S M X$, the initial concentration of SMX dropped from $18.98 \mathrm{mg} \cdot \mathrm{L}^{-1}$ to $4.09 \mathrm{mg} \cdot \mathrm{L}^{-1}$, while the removal efficiency was $78.45 \%$ within $48 \mathrm{~h}$. The concentration of $\mathrm{Zn}^{2+}$ was decreased from $97.47 \mathrm{mg} \cdot \mathrm{L}^{-1}$ to $45.90 \mathrm{mg} \cdot \mathrm{L}^{-1}$ with the removal efficiency of $52.91 \%$ in $48 \mathrm{~h}$. During the simultaneous removal of SMX and $\mathrm{Zn}^{2+}$, The corresponding removal rates of SMX and $\mathrm{Zn}^{2+}$ were $0.310 \mathrm{mg} \cdot \mathrm{L}^{-1} \cdot \mathrm{h}$ and $1.074 \mathrm{mg} \cdot \mathrm{L}^{-1} \cdot \mathrm{h}$, respectively.

The relationship between SMX transformation and $\mathrm{Zn}^{2+}$ removal effect was analyzed through comprehensive analysis: First, SMX was preferentially bioremoved by SDB4 as a carbon source. Meanwhile, the concentration of $\mathrm{Zn}^{2+}$ was slightly removed in the first $6 \mathrm{~h}$. SDB4 can rapidly remove SMX and a small amount of $\mathrm{Zn}^{2+}$ in the adaptive period, which indicates that SDB4 can adapt to the new liquid culture environment quickly. Compared with other strains, SDB4 has a short adaptation period (Su et al. 2019). Secondly, the decline of $S M X$ concentration and the exponential increase of $O_{600}$ promoted $Z^{2+}$ to be removed at a high rate in the 6-18 h period, while SMX was also rapidly removed. These results show that strain SDB4 can adapt to SMX and $\mathrm{Zn}^{2+}$ combined pollution environment well, meanwhile it grow at high speed in the complex contaminants system. The biomass reached a high level, which could 
remove the compound pollutants effectively. Both SMX and $\mathrm{Zn}^{2+}$ can be removed at a faster rate in the biomass logarithmic growth period, indicating that high concentration of biomass was able to improve the efficiency of various biochemical reactions. Dong has obtained similar conclusion (Dong and $\mathrm{Hu}$ 2021). Thirdly, when the SMX and $\mathrm{Zn}^{2+}$ concentration reduced to about $4 \mathrm{mg} \cdot \mathrm{L}^{-1}$ and $46 \mathrm{mg} \cdot \mathrm{L}^{-1}$, respectively. The cells of SDB4 started increase slowly, the SMX and $\mathrm{Zn}^{2+}$ removal rate became slower and the removal reaction reached balance. Consistent with the study of Shao et al., when the biomass of SDB4 increased slowly in the stationary period, the pollutants were no longer removed rapidly (Shao et al. 2018). Consequently, compared to the strains in previous research, SDB4 can not only remove SMX effectively, but also has excellent performance in removing SMX and $\mathrm{Zn}^{2+}$ simultaneously (Wang and Wang 2018).

\subsection{Possible removal mechanisms}

\subsubsection{SMX biotransformation pathway}

The main mechanism of SMX bioremoval was considered to be through biotransformation. The possible biotransformation metabolites of SMX in single and binary system were explored for further clarification of SMX bioremoval process. An intermediate product of SMX biotransformation was found in both systems. The intermediates were identified by detection and analysis of samples at $48 \mathrm{~h}$ with UHPLC-MSMS. Extracted ion chromatogram (EIC) in the full scan mode indicated that the retention time of the intermediate was $3.46 \mathrm{~min}$ and $3.45 \mathrm{~min}$, respectively (Fig. 5a, C). The peak area of binary system was larger than that of sole system, corresponding to low concentration coexisting $\mathrm{Zn}^{2+}$ promoting SMX bioremoval. The MS-MS full-scan spectrums of the intermediates were acquired in the positive ion mode (Fig. 5b, d). Both dominant ion peaks of the intermediate were at $\mathrm{m} / \mathrm{z} 134$ and 198, which were consistent with $\mathrm{N}^{4}$-acetyl-SMX (Ac-SMX), the transformation products of SMX.

Biodegradation and biotransformation are expected to be effective ways for eliminating SMX (Yang et al. 2016). Previous study indicated that $\mathrm{N}$-hydroxy-SMX and $\mathrm{N}^{4}$-acetyl-SMX represented the main stable metabolities in SMX biotransformation process when the antibiotic was used as the carbon source (Zhang et al. 2016). HO-SMX is more stubborn than SMX in the environment. Ac-SMX is less toxic than the parent compound, meanwhile acetylation is an important way to eliminate many therapeutic drugs (Reis et al. 2018). In this study, only one product $\mathrm{N}^{4}$-acetyl-SMX was detected. According to the structure of metabolite compound, arylamine $\mathrm{N}$-acetyltransferases might be involved in the biotransformation of SMX by SDB4. As demonstrated in the previous study, SMX could be transformed into Ac-SMX by arylamine $\mathrm{N}$-acetyltransferase (Zhang et al. 2016). The functional arylamine $\mathrm{N}$-acetyltransferase enzyme BanatC encoded from gene banatC in the pathogen Bacillus anthracis, was found able to acetylate the sulfonamide antibiotic SMX (Pluvinage et al. 2007). The arylamine N-acetyltransferases Nat-a and Nat-b, which purified and characterized from Bacillus cereus 10-L-2, was able to converte various aniline compounds into corresponding acetanilides and played a role in detoxification (Takenaka et al. 2009). In the process of SMX biotransformation by SDB4, a metabolite $\mathrm{N}^{4}$-acetyl-SMX was found, whose toxicity 
was around 10\% of SMX (Majewsky et al. 2014). This pathway could detoxify SMX effectively and environmentally friendly.

\subsubsection{FTIR analysis}

FTIR analysis was carried out to determine which functional groups of SDB4 were involved in $\mathrm{Zn}^{2+}$ adsorption. The uptake of heavy metal ions by functional groups will lead to higher or lower frequency shift of the spectrum (Rahim et al. 2020). The spectra in Fig. 6 shows that the band intensities of different regions have changed after the cells were contacted with single $\mathrm{Zn}^{2+}$ and $\mathrm{SMX}-\mathrm{Zn}^{2+}$ combined pollutants. The peak value corresponded to $\mathrm{OH}$ moved from $3294 \mathrm{~cm}^{-1}$ to $3298 \mathrm{~cm}^{-1}$ after zinc biosorption in both systems. The peaks observed at $1630-1680 \mathrm{~cm}^{-1}$ corresponded to $\mathrm{C}=\mathrm{O}$ in amide I band, while the at $1530-1630 \mathrm{~cm}^{-1}$ were for $\mathrm{C}-\mathrm{N} / \mathrm{N}-\mathrm{H}$ component of amide II in amide II band. The red shifts of amide bands I and II show that $\mathrm{C}=0, \mathrm{C}-\mathrm{N} / \mathrm{N}-\mathrm{H}$ play significant roles in the biosorption of $\mathrm{Zn}^{2+}$, which is consistent with the results obtained by other researchers (Li et al. 2019). The polysaccharide groups were determined by vibrations at $1050-1090 \mathrm{~cm}^{-1}$, the red shift (from $1071 \mathrm{~cm}^{-1}$ to $1051 \mathrm{~cm}^{-1}$ and $1054 \mathrm{~cm}^{-1}$, respectively) indicates that $\mathrm{C}-0-\mathrm{C}$ is also involved in $\mathrm{Zn}^{2+}$ biosorption. In the sole and binary pollution systems, the disappearance of characteristic peaks related to hydroxyl groups on carboxylic acid suggestes that $\mathrm{OH}$ participated in $\mathrm{Zn}^{2+}$ adsorption. The bending at $600-750 \mathrm{~cm}^{-1}$ represented amino groups, the shift and disappearance of amino group peaks, indicating the interaction of $\mathrm{NH}_{2}$ in $\mathrm{Zn}^{2+}$ bioaccumulation. All the above implied the hydroxyl, amino, amide and polysaccharides played important roles in the biosorption of $\mathrm{Zn}^{2+}$ by SDB4.

In conclusion, SDB4 can not only biotransform SMX/biosorp $\mathrm{Zn}^{2+}$ in the sole pollution system, but also remove the two pollutants simultaneously in the binary pollution system. We proposed the mechanism of simultaneous removal of SMX and $\mathrm{Zn}^{2+}$ by SDB4 (Fig. 7).

\section{Conclusions}

A simultaneous SMX biotransformating and $\mathrm{Zn}^{2+}$ bioremoving Bacillus sp. strain SDB4, was isolated from duck manure in a farm, Shandong Province, China. In the single system, the strain showed effective bioremoval performance to SMX and $\mathrm{Zn}^{2+}$, respectively. In the SMX-Zn ${ }^{2+}$ binary system, $20 \mathrm{mg} \cdot \mathrm{L}^{-1} \mathrm{SMX}$ and $100 \mathrm{mg} \cdot \mathrm{L}^{-1} \mathrm{Zn}^{2+}$ were removed simultaneously by strain SDB4 in $48 \mathrm{~h}$, with SMX biotransformation rate of $0.310 \mathrm{mg} \cdot \mathrm{L}^{-1} \cdot \mathrm{h}^{-1}$ and $\mathrm{Zn}^{2+}$ removal rate of $1.074 \mathrm{mg} \cdot \mathrm{L}^{-1} \cdot \mathrm{h}^{-1}$. The bioremoval ability of SMX was slightly improved at lower $\mathrm{Zn}^{2+}$ concentration $\left(<100 \mathrm{mg} \cdot \mathrm{L}^{-1}\right)$ as a result of $\mathrm{Zn}^{2+}$ accelerated the transportation of SMX from extracellular solution to inside cells during the reaction, but dropped with increase of $\mathrm{Zn}^{2+}$ concentration $\left(>100 \mathrm{mg} \cdot \mathrm{L}^{-1}\right)$. Furthermore, the bioremoval mechanisms were investigated by UHPLC-MS-MS, strain SDB4 possessed the same biotransformation route of SMX in both SMX single and SMX-Zn ${ }^{2+}$ binary pollutants removal systems. The functional groups of , $\mathrm{NH}_{2}, \mathrm{C}=\mathrm{O}, \mathrm{C}-$ $\mathrm{N} / \mathrm{N}-\mathrm{H}$ and $\mathrm{C}-\mathrm{O}-\mathrm{C}$ were mainly involved in $\mathrm{Zn}^{2+}$ bioremoval. This study indicates that Bacillus sp. strain 
SDB4 has an important potential for microbial remediation of SMX and $\mathrm{Zn}^{2+}$ contaminants and the applied experiments in practical complex polluted wastewater treatment will be carried out.

\section{Declarations}

Ethics approval and consent to participate: Not applicable.

Consent for publication: Not applicable.

Availability of data and materials: Not applicable.

Competing interests: The authors declare no competing interests.

Funding: The National Natural Science Foundation of China (51874018) and the Major Science and Technology Program for Water Pollution Control and Treatment of China (2015ZX07205003) provide all the funds for this research.

Authors'contributions Xi Chen: conceptualization, methodology, writing-original draft, investigation, formal analysis, data curation; Hai Lin: conceptualization, supervision, validation, resources, writingreview\&editing, funding acquisition, project administration; Yingbo Dong: conceptualization, methodology, supervision, writing-review\&editing, funding acquisition; Bing Li: investigation, conceptualization; Tingting Yin: formal analysis; Chenjing Liu: writing-review\&editing.

Acknowledgements: This work was financially supported by the National Natural Science Foundation of China (51874018) and the Major Science and Technology Program for Water Pollution Control and Treatment of China (2015ZX07205003).

\section{References}

1. Al-Gheethi A, Lalung J, Noman E, Bala JD, Ismail N (2015) Removal of heavy metals and antibiotics from treated sewage effluent by bacteria. Clean Technol Envir 17:2101-2123

2. Chen BW, Lin L, Fang L, Yang Y, Chen EZ, Yuan K, Zou SC, Wang XW, Luan TG (2018) Complex pollution of antibiotic resistance genes due to beta-lactam and aminoglycoside use in aquaculture farming. Water Res 134:200-208

3. Chen JF, Xie SG (2018) Overview of sulfonamide biodegradation and the relevant pathways and microorganisms. Sci Total Environ 640-641:1465-1477

4. Christou A, Aguera A, Bayona JM, Cytryn E, Fotopoulos V, Lambropoulou D, Manaia CM, Costas M, Mike R, Peter S (2017) The potential implications of reclaimed wastewater reuse for irrigation on the agricultural environment: The knowns and unknowns of the fate of antibiotics and antibiotic resistant bacteria and resistance genes- $A$ review. Water Res 123:448-467

5. Deng JQ, Li XD, Wei X, Liu YG, Liang J, Song B, Shao YN, Huang W (2020) Hybrid silicate-hydrochar composite for highly efficient removal of heavy metal and antibiotics: Coadsorption and mechanism. 
Chem Eng J 387:124097

6. Deng MC, Li J, Liang FR, Yi MS, Xu XM, Yuan JP, Peng J, Wu CF, Wang JH (2014) Isolation and characterization of a novel hydrocarbon-degrading bacterium Achromobacter sp. HZ01 from the crude oil-contaminated seawater at the Daya Bay, southern China. Mar Pollut Bull 83:79-86

7. Dong HL, Hu YY (2021) Application of a heavy metal-resistant Achromobacter sp. for the simultaneous immobilization of cadmium and degradation of sulfamethoxazole from wastewater. $J$ Hazard Mater 402:124032

8. He XL, Xu YB, Chen JL, Ling JY, Li YF, Huang L, Zhou X, Zheng L, Xie GY (2017) Evolution of corresponding resistance genes in the water of fish tanks with multiple stresses of antibiotics and heavy metals. Water Res 124:39-48

9. Hou TY, Du HW, Yang Z, Tian ZQ, Shen SC, Shi YX, Yang WB, Zhang LM (2019) Flocculation of different types of combined contaminants of antibiotics and heavy metals by thermo-responsive flocculants with various architectures. Sep Purif Technol 223:123-132

10. Huang MH, Tian SX, Chen DH, Zhang W, Wu J, Chen L (2012) Removal of sulfamethazine antibiotics by aerobic sludge and an isolated Achromobacter sp.S-3. J Environ Sci-China 24(9):1594-1599

11. Jin Y, Qu J, Li Y, Gu H, Yan L, Sun X (2013) Isolation, identification and Pb(II) biosorption characterization of a lead-resistant strain. Acta Scien Circum 33:2248-2255

12. Li J, Xu Y, Wang LQ, Li FD (2019) Heavy metal occurrence and risk assessment in dairy feeds and manures from the typical intensive dairy farms in China. Envir Sci Pollut Res 26(7):6348-6358

13. Li QH, Song WF, Sun MG, Li JY, Yu ZF (2019) Composition change and adsorption performance of EPS from Bacillus vallismortis sp. induced by $\mathrm{Na}_{2} \mathrm{~S}$. Ecotox Environ Safe 185:109679

14. Lillenberg M, Yurchenko S, Kipper K, Herodes K, Pihl V (2010) Presence of fluoroquinolones and sulfonamides in urban sewage sludge and their degradation as a result of composting. Int $J$ Environ Sci Te 7(2):307-312

15. Lin M, Hu XK, Chen WW, Wang H, Wang CY (2014) Biodegradation of phenanthrene by Pseudomonas sp. BZ-3, isolated from crude oil contaminated soil. Int Biodeter Biodegr 94:176-181

16. Liu XH, Zhang HB, Li LZ, Fu CC, Tu C, Huang YJ, Wu LH, Tang JH, Luo YM, Christie P (2016) Levels, distributions and sources of veterinary antibiotics in the sediments of the Bohai Sea in China and surrounding estuaries. Mar Pollut Bull 109:597-602

17. Liu Y, Du J, Lai QL, Zeng RY, Ye DZ, Xu J, Shao ZZ (2017) Proposal of nine novel species of the Bacillus cereus group. Int J Syst Evol Micr 67(8):2499-2508

18. Ma J, Xiong YC, Dai XH, Yu F (2020) Coadsorption behavior and mechanism of ciprofloxacin and $\mathrm{Cu}(\mathrm{II})$ on graphene hydrogel wetted surface. Chem Eng J 380:122387

19. Ma Y, Zhou Q, Zhou SC, Wang W, Jin J, Xie JW, Li AM, Shuang CD (2014) A bifunctional adsorbent with high surface area and cation exchange property for synergistic removal of tetracycline and Cu2 ${ }^{+}$. Chem Eng J 258:26-33 
20. Majewsky M, Wagner D, Delay M, Brase S, Yargeau V, Horn H (2014) Antibacterial Activity of Sulfamethoxazole Transformation Products (TPs): General Relevance for Sulfonamide TPs Modified at the para Position. Chem Res Toxicol 27:1821-1828

21. Pan LJ, Li J, Li CX, Tang XD, Yu GW, Wang Y (2018) Study of ciprofloxacin biodegradation by a Thermus sp. isolated from pharmaceutical sludge. J Hazard Mater 343:59-67

22. Pluvinage B, Dairou J, Possot OM, Martins M, Fouet A, Dupret JM, Rodrigues-Lima F (2007) Cloning and molecular characterization of three arylamine $\mathrm{N}$-acetyltransferase genes from Bacillus anthracis: identification of unusual enzymatic properties and their contribution to sulfamethoxazole resistance. Biochemistry-Us 46:7069-7078

23. Qi CD, Liu XT, Lin CY, Zhang XH, Ma J, Tan HB, Ye W (2014) Degradation of sulfamethoxazole by microwave-activated persulfate: Kinetics, mechanism and acute toxicity. Chem Eng J 249:6-14

24. Qin HQ, Hu TJ, Zhai YB, Lu NQ, Aliyeva J (2020) The improved methods of heavy metals removal by biosorbents: A review. Environ Pollut 258:113777

25. Rahim ARA, Mohsin HM, Thanabalana M, Rabat NE, Saman N, Mat H, Johari K (2020) Effective carbonaceous desiccated coconut waste adsorbent for application of heavy metal uptakes by adsorption: Equilibrium, kinetic and thermodynamics analysis. Biomass Bioenerg 142:105805

26. Reis PJM, Homem V, Alves A, Vilar VJP, Manaia CM, Nunes OC (2018) Insights on sulfamethoxazole bio-transformation by environmental Proteobacteria isolates. J Hazard Mater 358(15):310-318

27. Riaz L, Wang QQ, Yang QX, Li XN, Yuan W (2020) Potential of industrial composting and anaerobic digestion for the removal of antibiotics, antibiotic resistance genes and heavy metals from chicken manure. Sci Total Environ 718:137414

28. Shah A, Shah M (2020) Characterisation and bioremediation of wastewater: A review exploring bioremediation as a sustainable technique for pharmaceutical wastewater. Groundwater for Sustainable Development 11:100383

29. Shao SC, Hu YY, Cheng C, Cheng JH, Chen YC (2018) Simultaneous degradation of tetracycline and denitrification by a novel bacterium, Klebsiella sp. SQY5. Chemosphere 209:35-43

30. Shao YY, Gao Y, Yue QY, Kong WJ, Gao BY, Wang WG, Jiang WQ (2020) Degradation of chlortetracycline with simultaneous removal of copper (II) from aqueous solution using wheat strawsupported nanoscale zero-valent iron. Chem Eng J 379:122384

31. Sherameti I, Varma A (2010) Soil Heavy Metals. Soil Heavy Metals

32. Su JF, Gao CY, Huang TL, Gao YC, Bai XC, He L (2019) Characterization and mechanism of the Cd(II) removal by anaerobic denitrification bacterium Pseudomonas sp. H117. Chemosphere 222:970-979

33. Takenaka S, Cheng MY, Mulyono, Koshiya A, Murakami S, Aoki K (2009) Gene cloning and characterization of arylamine N-acetyltransferase from Bacillus cereus strain 10-L-2. J Biosci Bioeng 107:27-32

34. Tang SY, Yin H, Zhou S, Chen SN, Peng H, Liu ZH, Dang Z (2016) Simultaneous Cr(VI) removal and 2,2',4,4'-tetrabromodiphenyl ether (BDE-47) biodegradation by Pseudomonas aeruginosa in liquid medium. Chemosphere 150:24-32 
35. Trenouth WR, Gharabaghi B (2015) Soil amendments for heavy metals removal from stormwater runoff discharging to environmentally sensitive areas. J Hydrol 529(3):1478-1487

36. Tullo E, Finzi A, Guarino M (2019) Review: Environmental impact of livestock farming and Precision Livestock Farming as a mitigation strategy. Sci Total Environ 650:2751-2760

37. Verma S, Kuila A (2019) Bioremediation of heavy metals by microbial process. Environ Technol Inno 14:100369

38. Wang JL, Wang SZ (2018) Microbial degradation of sulfamethoxazole in the environment. Appl Microbiol Biotechnol 102:3573-3582

39. Wang SZ, Wang JL (2018) Biodegradation and metabolic pathway of sulfamethoxazole by a novel strain Acinetobacter sp. Appl Microbiol Biotechnol 102:425-432

40. Xing BS, Jin RC (2018) Inhibitory effects of heavy metals and antibiotics on nitrifying bacterial activities in mature partial nitritation. Chemosphere 200:437-445

41. Xu YG, Yu YT, Ma Q, Wang J, Qiang, Zhou H, Jiang CM (2016) The combined effect of sulfadiazine and copper on soil microbial activity and community structure. Ecotox Environ Safe 134(1):43-52

42. Xu ZG, Yi D, Huang HM, Wu L, Zhao YL, Yang GY (2019) Biosorption Characteristics of Mn ( $(\mathbb{Z})$ by Bacillus cereus Strain HM- 5 Isolated from Soil Contaminated by Manganese Ore. Pol J Environ Stud 28:463-472

43. Yang CW, Hsiao WC, Chang BV (2016) Biodegradation of sulfonamide antibiotics in sludge. Chemosphere 150:559-565

44. Zhang TT, Wang MM, Yang WB, Yang Z, Wang YP, Gu ZG (2014) Synergistic Removal of Copper(II) and Tetracycline from Water Using an Environmentally Friendly Chitosan-Based Flocculant. Ind Eng Chem Res 53:14913-14920

45. Zhang WW, Qiu LN, Gong AJ, Yuan XT (2017) Isolation and characterization of a high-efficiency erythromycin A-degrading Ochrobactrum sp strain. Mar Pollut Bull 114:896-902

46. Zhang YB, Zhou J, Xu QM, Cheng JS, Luo YL, Yuan YJ (2016) Exogenous cofactors for the improvement of bioremoval and biotransformation of sulfamethoxazole by Alcaligenes faecalis. Sci Total Environ 565:547-556

\section{Figures}




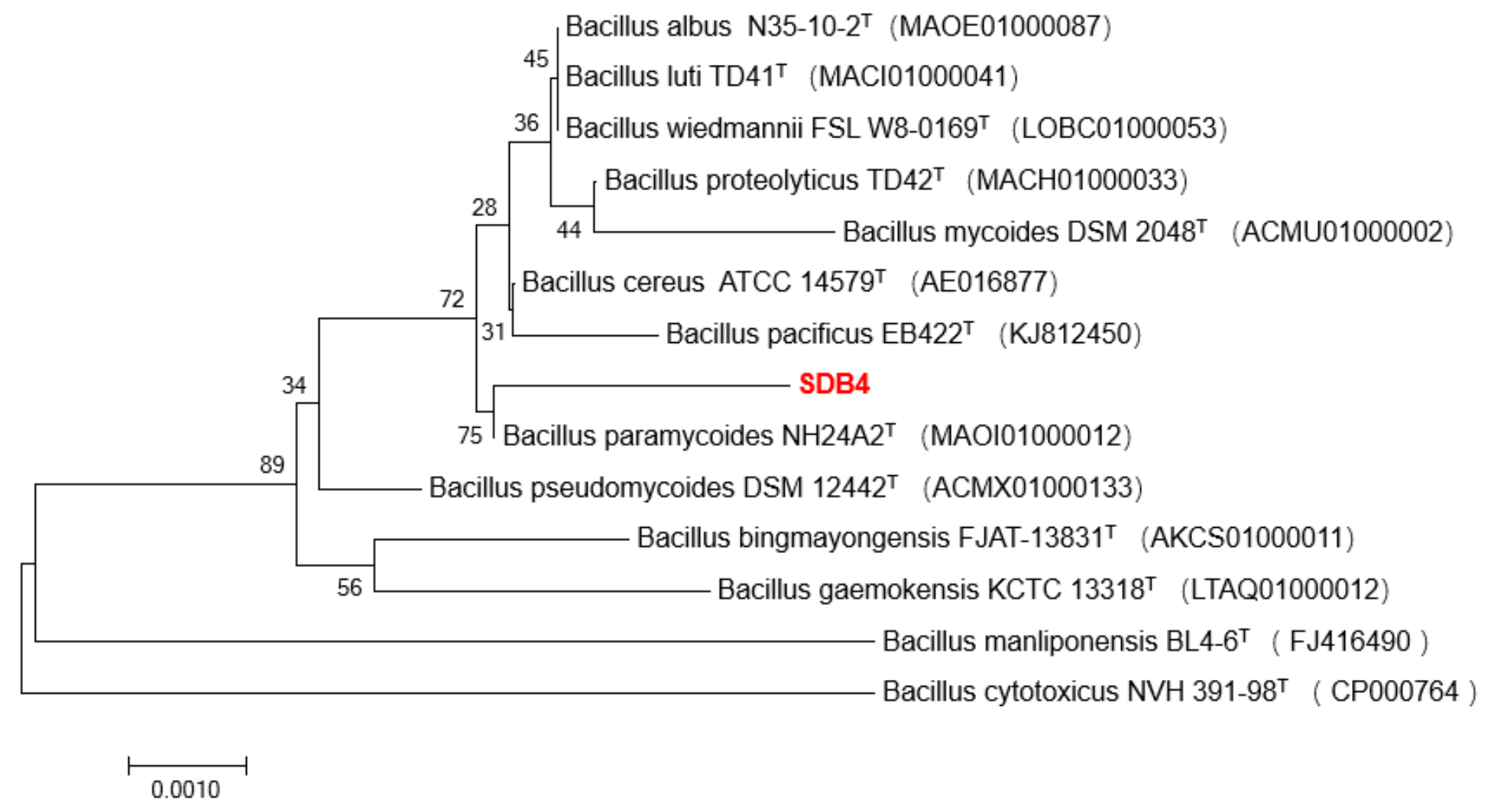

Figure 1

Phylogenetic tree based on the $16 \mathrm{~S}$ rDNA gene, indicating the relationships between strain Bacillus sp. SDB4 and associated strains.
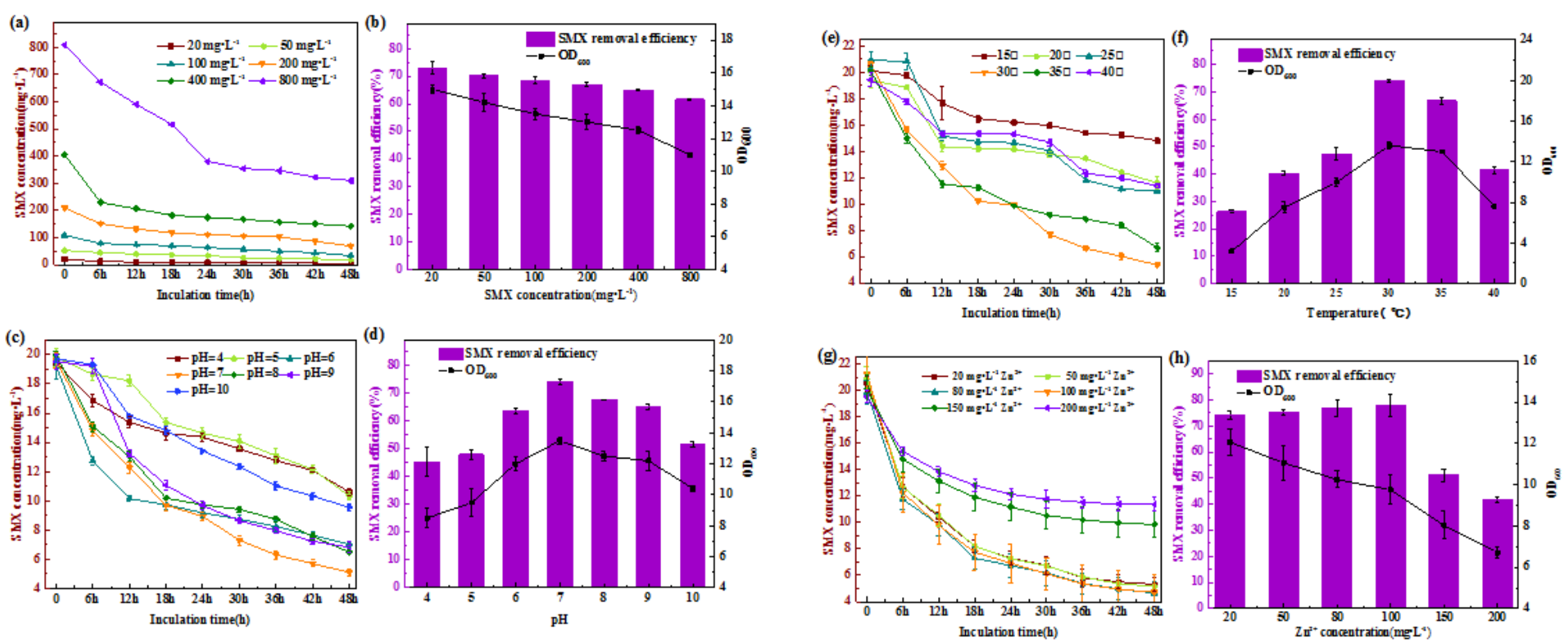

Figure 2

Effects of initial SMX concentration $(a, b), p H(c, d)$, temperature $(e, f)$ and coexisted $Z n 2+$ concentration $(\mathrm{g}, \mathrm{h})$ on SMX bioremoval. 

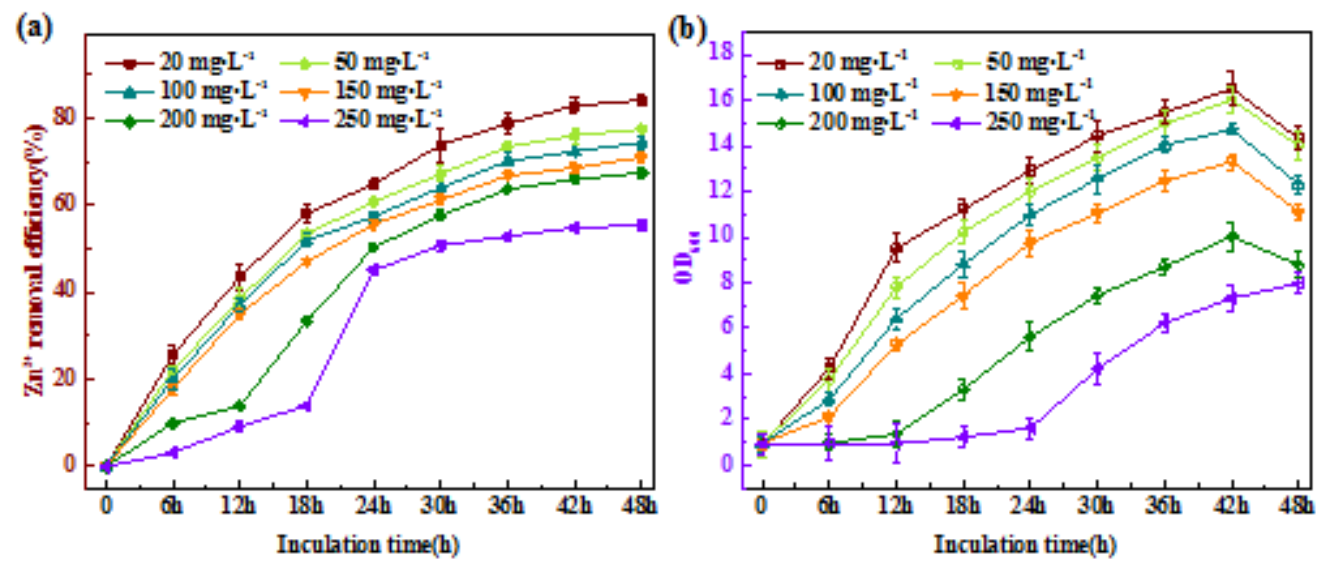

Figure 3

Effect of inoculation time on the bioremoval efficiency of Zn2+ (a) and OD600(b).
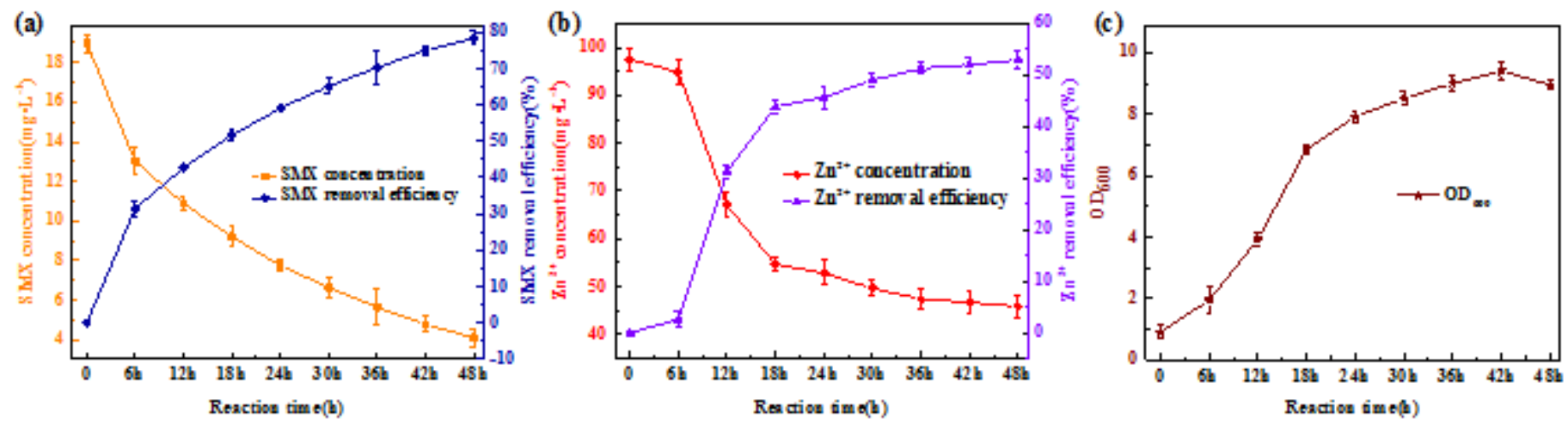

Figure 4

Changes of SMX concentration and removal efficiency (a), changes of Zn2+ concentration and removal efficiency (b), changes of OD600 (c) in the SMX-Zn2+ binary system. 

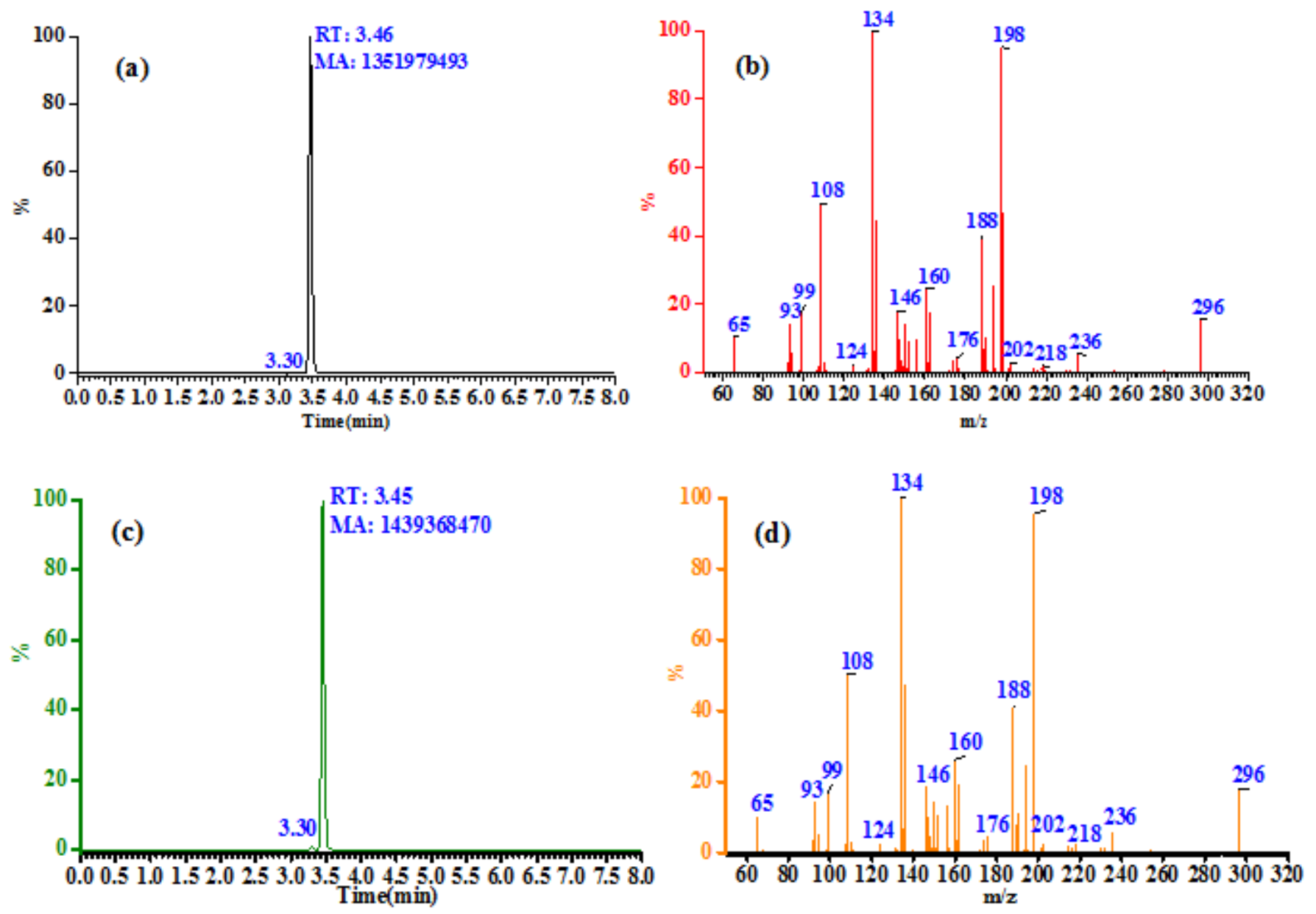

Figure 5

Extracted ion chromatograms (EIC) and tandem mass spectrum of SMX biotransformation products. EIC of the $48 \mathrm{~h}$ sample of SMX biotransformation (a) and tandem mass spectrum of the intermediate product of SMX biotransformation (b) in sole system; EIC of the $48 \mathrm{~h}$ sample of SMX biotransformation (c) and tandem mass spectrum of the intermediate product of SMX biotransformation (d) in binary system. 


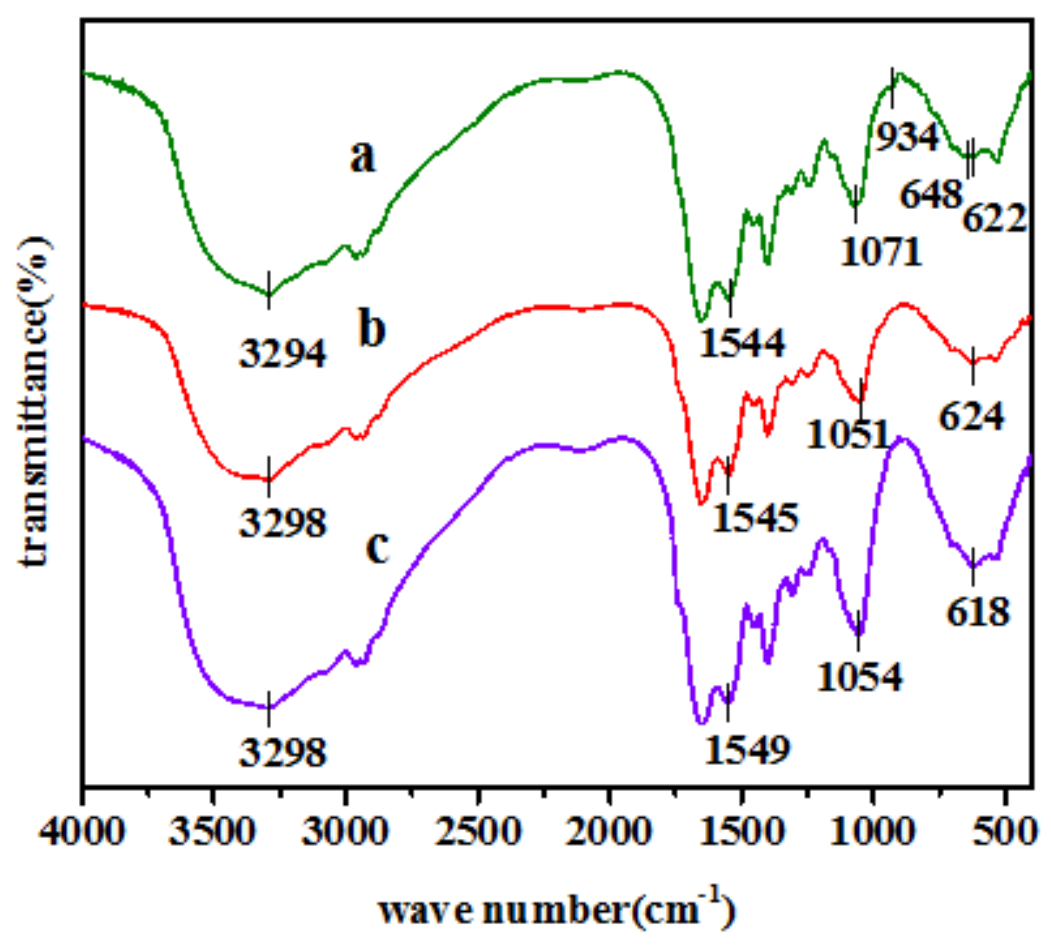

Figure 6

FTIR spectra of strain SDB4 before (a), after (b) Zn2+ bioremoval and simultaneous bioremoval of SMX and $\mathrm{Zn} 2+(\mathrm{c})$.

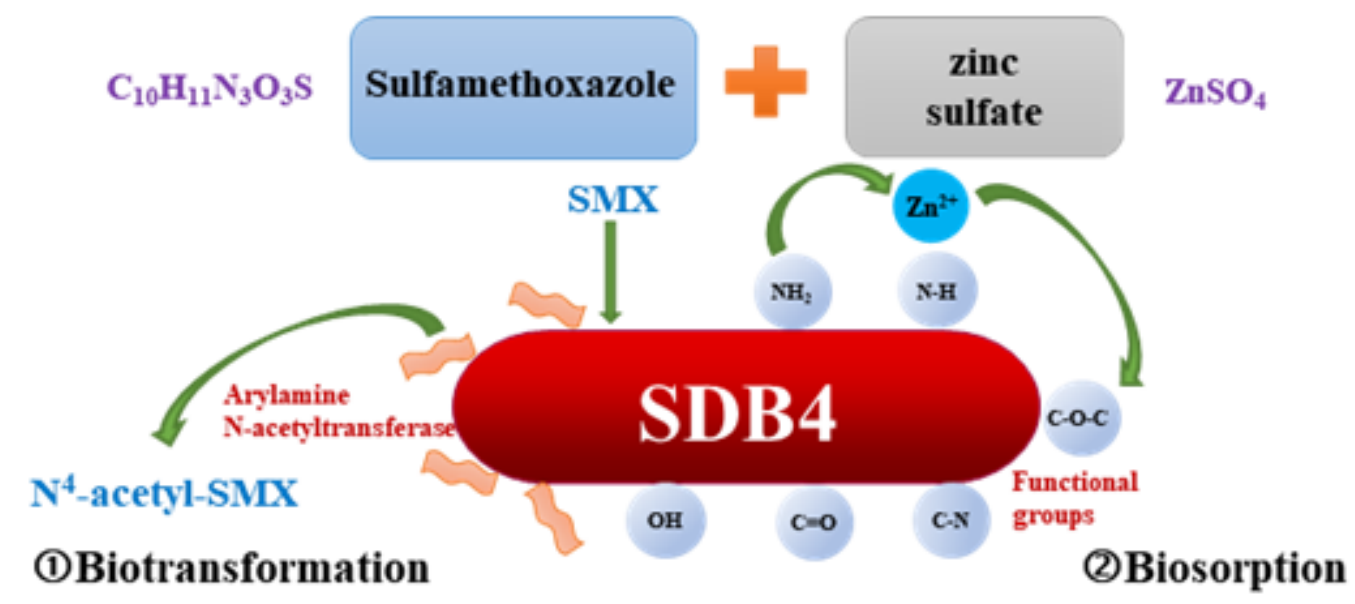

Figure 7

Possible pathway for simultaneous biotransformation of SMX and biosorption of Zn2+ by strain SDB4. 